\title{
Assessing a Causal Relationship Between Foreign Direct Investment and Human Capital: The Case of the Netherlands
}

\author{
Jovanka Pinas ${ }^{1}$, Sun Wei ${ }^{1}$, Tetelesti Oppong-Baah ${ }^{1}$, Elina Kim ${ }^{1}$, Mabel Addai ${ }^{1}$, Isaac Owusu ${ }^{1}$, Edward Gyamfi ${ }^{2}$, \\ Deborah Ofosu ${ }^{1}$, Adjoa Afedua Nsaful ${ }^{1}$, Emmanuel Nketiah ${ }^{1}$, Mavis Adjei ${ }^{1}$, Abigail Afi Asamoah Asiamah ${ }^{1}$, \\ Frederick Adjei Boateng ${ }^{1}$, Christiana Twi-Brempong ${ }^{1}$, Samuel Koranteng Fianko ${ }^{3,4}$, Kweku Kyei Gyamerah ${ }^{5}$ \\ ${ }^{1}$ School of Business, Nanjing University of Information Science \& Technology, Nanjing 210044, China \\ ${ }^{2}$ College of Economics and Management, Nanjing Agricultural University, Nanjing 210095, China \\ ${ }^{3}$ Central University of Technology, Bloemfontein, South Africa \\ ${ }^{4}$ Marshalls University College, Accra, Ghana \\ ${ }^{5}$ Unibank Ghana Limited, P.O. Box 15367, Accra, Ghana \\ Correspondence: Tetelesti Oppong-Baah, School of Business, Nanjing University of Information Science \& \\ Technology, Nanjing 210044, China.
}

Received: November 14, 2019

doi:10.5539/ibr.v13n1p247
Accepted: December 17, 2019 Online Published: December 27, 2019

URL: https://doi.org/10.5539/ibr.v13n1p247

\begin{abstract}
Foreign direct investment is seen by many countries as an important source of capital. The flow of foreign direct investment in the world has been increasing over the past couple of years and many countries have adopted various institutional policies with the hope of attracting more foreign direct investment. Besides capital, these countries also get to benefit from the other advantages that these investments bring with them, such as the newest technology and managerial skills. FDI, besides boosting capital formation, also increases the quality of capital stock. Countries can only reap all the benefits of foreign direct investment if they have a sufficient amount of human capital. Human capital is seen by many researchers as one of the most important determinants of FDI. With the world becoming more knowledge-based and globalized the importance of human capital became very significant not only to individuals, but also to countries in their competitive advantages. The purpose of this research is to find out what the relationship is between foreign direct investment and human capital in the Netherlands. The Netherlands is a small country in Europe which has been a global leader in the inflow and outflow of FDI the past couple of years. This study uses the Augmented Dickey-Fuller test and the Johansen cointegration test to determine whether or not there is a causal relationship between the variable's foreign direct investment and secondary school enrollment, which is used as a proxy for human capital. The study observed that there is no causal relationship between foreign direct investment and human capital in the Netherlands. The inflow of human capital into the Netherlands is determined by other factors.
\end{abstract}

Keywords: foreign direct investment, human capital, Netherlands, Augmented Dickey-Fuller test and Johansen Cointegration test

\section{Introduction}

The flow of foreign direct investment (FDI) to and from countries increased tremendously in the past decades. According to Demir (2016), there has been a global rush in many countries improving and harmonizing their institutional environments with the hope of strengthening their competitive position. The United Nations Conference on Trade and Development World's Investment Report (2018) indicates that in 2017 at least 65 countries and economies adopted no more than 126 investment policy measures. Of all these measures at least, 84 percent were qualified as very favorable to investors. These countries liberalized entry conditions in different industries and by simplifying various administrative procedures, providing incentives and establishing new special economic zones this promoted and facilitated investment.

Foreign direct investment can be seen as a vehicle for the transfer of tangible assets like capital and intangible assets like technology, innovative product designs and managerial skills (Simionescu, 2016). According to Moran (2006) when companies decide to build foreign-owned plants to enter international markets, these plants are in most cases part of the parent multinational's own supply chain. They use and work with the most advanced 
technologies embodying the most refined and up to date quality control procedures. They also pay higher wages compared to other domestic companies and with the increasing complexity of their operations, they become attractive employers for more skilled workers and also offer superior and better working conditions. FDI is not only a source of finance and employment, but for developing countries, it can be used as a medium to alleviate their resources and skill constraints (Noorbakhsh et al., 2001).

As an engine of growth and development, foreign direct investment has many benefits. It includes serving as a source of capital, employment generation, facilitating access to foreign markets and generating technological and efficiency spillovers to local firms. Besides boosting capital formation, FDI also increases the quality of capital stock (Adefabi, 2011). According to Dorożyńska \& Dorożyński (2014), the transfer of knowledge can happen on many different levels. It can happen on an international level through the exchange of goods, services, technologies and the inflow of FDI.

Most researchers share the same meaning about FDI being beneficial to countries and their economic growth. Borenszstein, De Gregorio \& Lee (1995), however, explain that the increased productivity of FDI only holds when host countries have at least a minimum of threshold stock of human capital. They point out that some of the most technologically advanced firms in the world are Multinational corporations (MNC) and they account for a big part of the world's research and development investment. They introduce new capital goods at a lower cost since they possess more advanced knowledge. To be able to apply and use these advanced technologies, host countries need to have a sufficient amount of human capital. Kucharčíková (2013) points out that FDI can complement the domestic investment in countries and each form of FDI has a role to play in promoting countries their growth and sustainable development. It should boost their competitiveness, create jobs and decrease income and social inequality.

The United Nations Conference on Trade And Development (2018) defines FDI as an investment involving a long-term relationship and reflecting a lasting interest and control of a resident entity in one economy (foreign direct investor or parent enterprise) in an enterprise resident in an economy other than that of the foreign investor (FDI enterprise, foreign affiliate or affiliate enterprise). Based on this definition, one can assume that FDI in a broad sense involves the movement of assets (tangible and intangible) from one country to another. Countries can gain a lot from the benefits that come with FDI. Investors, on the other hand, have various reasons for investing abroad in other countries. Kucharčíková (2013) states that investors decide to invest abroad with the hope of obtaining new natural and human resources at a cheaper price than in their own domestic economy. It can be to find opportunities to market their products and to increase the efficiency of production, but most importantly to increase their own revenues.

Demirhan \& Masca (2008), share the same opinion pointing out that MNC's expand their activities to foreign countries for many reasons like the exploitation of economies of scale or scope, to use specific advantages owing to a life cycle pattern of their products or simply because their competitors are engaged in similar activities. As mentioned before in the case of Borenszstein et al. (1995) countries can only fully gain from FDI if they have enough human capital available to make good use of the new technologies foreign investors bring through FDI. Dorożyńska \& Dorożyński (2014) state that human capital is one of the most important factors in building a knowledge-based economy.

Knowledge, on the other hand, is one of the main drivers of innovation and development. Dorożyńska \& Dorożyński (2014) point out that human capital is a part of the investment climate of the economy and implies skilled labor, meaning skills that individuals possess and are acquired through investing in education and training of the population. A study done by Fazekas (2000) in Hungary shows that besides urban conglomeration and geographical location a higher level of education in a country could attract more FDI. According to him locations with a low employment rate in Hungary attracted more FDI and caused the creation of more jobs and a decrease in the unemployment rate.

Boarini \& Liu (2012) indicate that with the world becoming more knowledge-based and globalized the importance of human capital became very significant to both individuals and countries in their competitive advantages. Investing in human capital has many other benefits besides increasing a country's economic growth and some of these non-economic benefits include having a population with improved health status, enhanced personal well-being and greater social cohesion. As the United Nations Economic Commission for Europe (2016) notes, it is of significant importance to policymakers to understand their human capital and having the necessary statistics on their human capital can help these policymakers understand what the drivers are of economic growth and how the labor market functions, and how to assess long-term stability for their country's development path.

The World Economic Forum (WEF) (2017) defines human capital as the knowledge and skills people possess 
that gives them the opportunity to create value in their country's economic system and likewise the global economic system. Another definition according to the Organisation for Economic Co-operation and Development (2017) is that human capital is the knowledge, skills, competencies, and attributes embodied in individuals that facilitate the creation of personal, social and economic well-being. The WEF (2017) also states that based on the Global Human Capital Index which ranks at least 130 countries on a scale from 0 to 100 on how well they are developing their human capital, the world has developed only $62 \%$ of its human capital. This means that countries are wasting on average at least $38 \%$ of their human capital.

Countries with a longstanding commitment to their population's educational attainment are the leaders of this index. These countries have placed a large share of their workforce in skill-intensive businesses across different sectors. The United Nations Economic Commission for Europe (2016) highlights that in most production processes the input of humans is the major factor and the value of that input is for a big part dependent on the knowledge humans bring to the production process. The top 20 of the Global Human Capital Index consists mostly of European countries, with the United States, four countries from East Asia and the Pacific, three countries from Eastern Europe and central Asia and one country from the Middle East and North Africa.

The Netherlands, a small country located in Europe is ranked as no 13. The world financial and economic crises of 2008 reached many countries and it made them suffer big losses. The case in the Netherlands was no different (Figure 1-Left panel). The U.S. Department of State (2015), points out that the Netherlands has a very organized labor market existing of a well-educated, multilingual and motivated workforce (Figure 1-Right panel). In 2014, the annual unemployment rate was around 9\%, which is below the EU average. At least 7.85 million people make up the working population. In the case of FDI, they are global leaders with over USD 4.3 trillion as inward FDI and USD 5.2 trillion as outward FDI. According to UNCTAD's world investment report (2018), FDI flows from around the world fell by $23 \%$ to USD 1.43 trillion. This decrease was in contrast to the growth in GDP and trade. It was mostly caused by a decrease of $22 \%$ in the value of cross-border merger and acquisitions (M\&As).

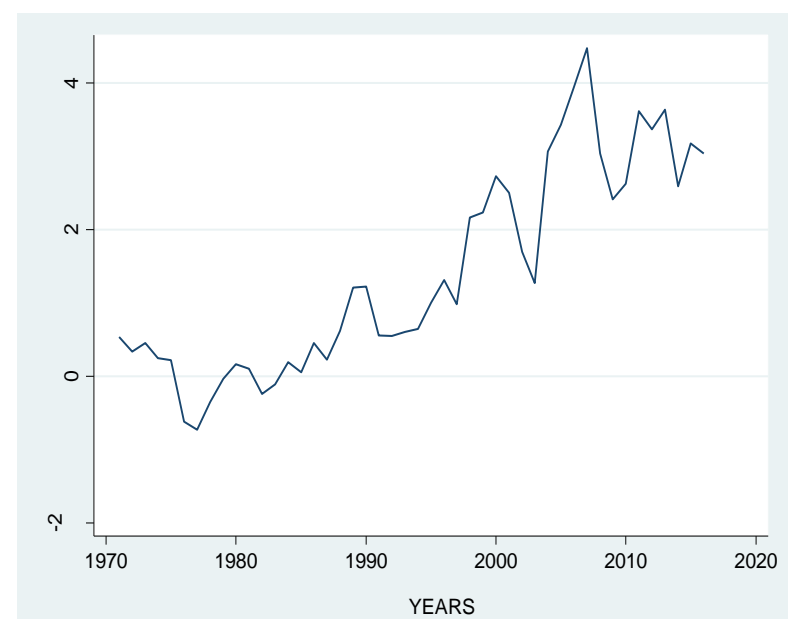

Figure 1. FDI inflow in the Netherlands

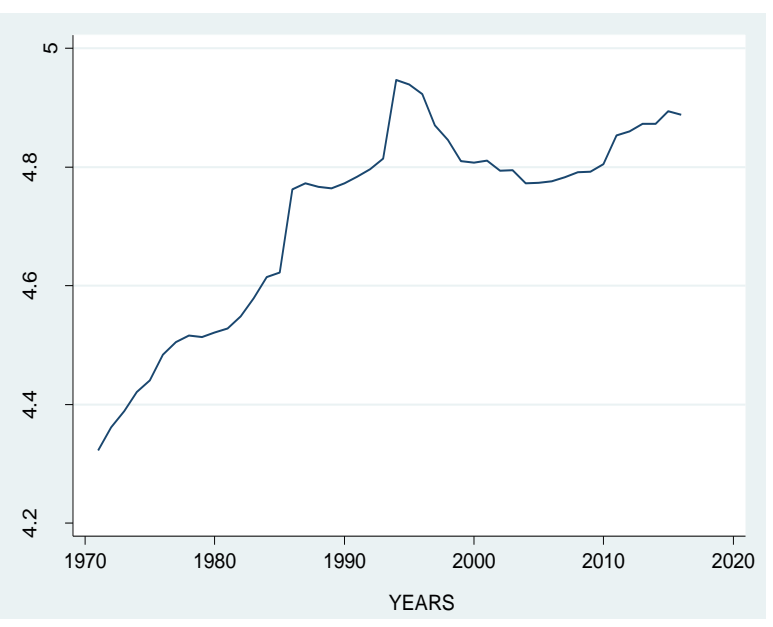

Figure 2. Netherlands Secondary school enrollment

Source: Authors computations based on WDI datasets

Figure 1: Left panel presents the inflow of foreign direct investment in the Netherlands. The figure shows that the inflow of FDI has been increasing every decade since 1980. Between 2000 and 2010, there was a decrease in the inflow of FDI which was due to the world crisis of 2008. Before the world crisis hit, however, the inflow was at its highest and up till now, it has never reached that level again. Figure 2: Right panel presents the increase in secondary school enrollment in the Netherlands. Secondary school enrollment is trending upwards and has been increasing from 1970 till date. The highest peak was between 1990 and 2000. It decreased at the beginning of 2010 and has been increasing again since then.

FDI flows into developed countries also decreased by $23 \%$ to USD712 billion and the Netherlands, the largest source country of FDI in the world also saw a decrease in their FDI inflow. They are the eighteenth largest economy in the world and as a member of the Eurozone the fifth largest economy (U.S. Department of state, 2015). Statistics Netherlands (2008) points out that when it comes to the investment climate of countries, the Netherlands has an average to good score for many aspects of the investment climate. Aspects such as the 
secondary conditions for economic growth, meaning the macro-economic conditions and functioning of the government. They also have a high score for human capital and the supply of labor. Being a host country to FDI has many benefits, but since the effects of these investment can't be measured in the same year, it is important to measure it over a series of years. The literature consists of many studies about the determinants of FDI and its effect on the growth of the economy. Much has not been done on how FDI affects countries their human capital over time and especially in a developed country. To add to the literature this research is based on the impact of FDI on human capital in the Netherlands.

The main reason for choosing the Netherlands is the fact that they are one of the top leaders in the world. They lead the table as the country with the most inward and outward FDI and consist of a well-educated workforce. The outcome of this research will provide insight into countries acting as a host and home country to FDI and bring forth whether countries suffer or gain from the inflow of FDI. Last but not least, it will serve as a reference to further studies in the area of FDI in other countries and how their human capital is affected. To find out the role of human capital in the world and how countries handle their human capital, the following research questions were posed.

1. What is the association between FDI and Human Capital?

2. What are the determinants and types of FDI?

3. How does the inflow of FDI affect Human Capital in the Netherlands?

In order to answer these research questions, the study formulated this hypothesis: Is there a causal relationship between the inflow of foreign direct investment and human capital in the Netherlands?

\section{Literature Review}

In the past decades, there has been an increase in the inflow and outflow of FDI amongst countries. Since the world crisis in 2008, global FDI has been increasing step by step. Developing countries are being more open to FDI, giving developed countries the opportunity to invest in these countries. There are also developed countries who invest in other developed countries and in this case, acting like both host and home countries to FDI. Jansen \& Stokman (2004), share the same opinion highlighting that developed countries in most cases act as a host to FDI in their own country and also participate in FDI projects in other countries.

Yu \& Walsh (2010) state that looking at the literature and the research that has been done, it is not clear that the factors attracting FDI in rich countries and developing countries are the same.

Developing countries are important destinations of FDI even though in most cases they seem to have higher inflation, poorer institutions, and lower development indicators. Firms investing in developing countries trade off greater macro stability and a better-educated labor force, which can be found in developed countries, for lower wages or access to a profitable but protected market in developing countries. Al-sadiq (2013) highlights that when countries decide to invest in other countries this causes a reduction in domestic investment in the home countries. He points out that by investing in another country and moving their production plants to that country they tend to cause a decrease in domestic exports. These outflows are seen as decreasing the domestic investment, but if the outflows are adding to the country's exports through production linkages than they can be seen as increasing the domestic investment.

According to the Global Human Capital Report (WEF, 2017) the world has only developed $62 \%$ of its human capital as measured by the human capital index. This means that at least 38\% of the world human capital is neglected or wasted and nations are not making use of their talents. The leaders of this index are economies who have a longstanding commitment to their people's education and a big part of their workforce is deployed in skill-intensive jobs making them the high-income economies in today's world. One significant interest to policymakers is to understand their human capital. Statistics on human capital can help policymakers understand the drivers of economic growth in their country and the functioning of the labor market (UNECE, 2016).

Human capital can either be enhanced through the use of these skills or either depreciated through lack of use of these skills. How countries develop their human capital can be seen as one of the most important determinants for their long-term success than any other factor (WEF, 2017). Kucharčíková (2013) explains in her paper that there are many reasons why investors decide to invest abroad. It is a chance to get access to new natural and human resources at a lower price than in their own economy. It can also be a way of finding new opportunities for marketing products and most importantly to increase their own revenue.

Human capital is one of the most important factors in building a knowledge-based economy and knowledge, on the other hand, is regarded by most researchers as one of the main drivers of innovation and development 
(Dorożyńska and Dorożyński, 2014). Human capital according to Noorbakhsh et al. (2001) is one of the most important and essential factors in attracting FDI together with trade openness, the growth rate of the market size and past changes in FDI inflows. Investments in human capital in countries can take the form of migration. These investments can cause skilled people to immigrate resulting in an increase of the stock of human capital for the country of destination and a decrease in the country of origin (Liu and Fraumeni, 2014).

The idea of emigrating and acquiring higher wages abroad when being highly skilled can motivate people to go for higher education levels (Dulam, 2015). A higher wage difference between the home country and the destination country can cause an increase in the emigration rate. A raise in wages and employment through FDI can reduce emigration, the creation of information links through FDI on the other hand results in the increase of emigration (Xu and Sylwester, 2016). Employees working for multinationals can gain knowledge and skills, which in the future in some cases can result in emigration. Dorożyńska and Dorożyński (2014) state that FDI one of the main factors is for the movement of technology across borders. It can cause competition in the host economy to increase by making domestic companies more efficient and it stimulates the diversification of sectors and products. Jude \& Silaghi (2015) highlight in their paper that FDI on the short-run leads to the destruction of labor markets but can result in the creation of jobs on the long-run. Their research, however, was limited to EU countries, explaining that FDI as a determinant of employment is limited when compared to output growth and economic restructuring.

\subsection{Determinants of Foreign Direct Investment}

Most countries do not have the finances to make the kind of investments they want to make. Many researchers agree with the fact that for some of these countries FDI can be seen as one of the solutions to their investment problem and in some cases also adding to the growth of their economy. According to Jansen \& Stokman (2004) the position of a country's FDI inflow is based on the hosted FDI projects and the outflow position on the FDI projects owned abroad in another country.

Elia, Mariotti \& Piscitello (2009) highlight that outward FDI not only directly affects the parent company's domestic employment, but also indirectly affects the business environment in which it operates. They also explain that producing in foreign branches can cause substitutive effects on domestic employment in which these MNCs operate. These substitutive effects, on the other hand, can result in a decrease of the domestic low skilled labor force, a loss of the market shares by local suppliers and the opportunity to learn from the parent company disappears also. Another type of effects are complementary effects. In this case, when a company transfers the production abroad it can have positive effects for host countries when the suppliers of the parent company become the suppliers of the foreign branches.

Looking at the various variables which can have an impact on FDI flows, Yu \& Walsh (2010) point out several and these are: the size and growth potential of the host market, economic stability, and the degree of openness of the host economy and income level, as well as the quality of institutions and level of development. Demir (2016) states that corruption, government stability, investment profile, and law and order are some of the most important determinants of FDI and also have the most effect on FDI flows. Noorbakhsh et al. (2001) note that the determinants of FDI still make up for a large part of FDI inflows in the world. Some of these determinants are the availability of natural resources, access to local markets and the cost of labor.

\subsubsection{Labor Cost and Productivity Growth}

Noorbakhsh et al. (2001) point out that with the new technological advantages in the world, FDI shifted towards more capital-, knowledge-, and skill-intensive industries. Countries with a well-educated workforce have increased their chances of attracting more FDI since this has become more attractive to MNCs compared to low labor costs. According to Chakrabarti (2011) of all the determinants of FDI, wage as an indicator of labor cost has been the most controversial. There is no unanimity amongst the studies exploring the role of wage in effecting FDI. Some say higher wages decrease the inflow of FDI, while others found no significant effect or a positive relationship between the two. He further explains that when there's not that big of a difference in the cost of labor in the home and host country, the skills of the labor force will be the one to have an impact on the location of FDI. Noorbakhsh et al. (2001) explain that in the case of developing countries, the cost of labor is regarded as an important determinant for labor-intensive and efficiency-seeking FDI since labor in developing countries cost less than in developed countries.

\subsubsection{Market Size and Growth Potential}

For the efficient utilization of resources and exploitation of economies, a large market is needed and as the market-size grows, FDI will start to increase thereafter with its further expansion. Faster growing markets create 
better opportunities for firms to acquire more profits than market who grow slowly or don't grow at all (Chakrabarti, 2011). Zhang \& Daly (2011) also share the opinion that the larger the size of the market, the more FDI the host country will attract and thus giving foreign investors more opportunities in the market.

\subsubsection{Trade Openness}

A country can attract more horizontal FDI if they decrease their openness since firms can escape trade barriers through building production sites abroad (Xu and Sylwester 2016). As noted by Demirhan \& Masca (2008), it is the type of investment that decides how big of an impact openness can have on FDI. This means that foreign firms aiming to serve local markets may set up branches or affiliates in the host country if it is too difficult to import their products to that country. Export-oriented firms, on the other hand, may want to invest in economies that are more open since trade protection indicate higher transaction costs associated with those exports. According to Noorbakhsh et al. (2001), open economies whether small or not show more confidence and encourage foreign investments. According to Das (2013), the openness of countries influences FDI positively. By expanding their trade activities countries give domestic firms the opportunity to gain knowledge about foreign countries and their markets. They get to learn various skills related to organizing foreign operations and also to advertise their products on an international level. He further explains that a high degree of trade openness exposes countries to foreign markets.

\subsubsection{Exchange Rate Valuation}

According to Yu \& Walsh (2010), countries with a weak real exchange rate attract more vertical FDI, because this can be an advantage to firms as low prices in host markets are used to buy facilities and obtain more home-country profits on goods that are sent to third markets. Das (2013) points out that a strong currency favors outward investment since it gives investors the ability to buy more. If the home country currency appreciates, the capital requirements of foreign investors in domestic currency are in this case lower which makes it easier for these investors to raise capital than in the case of a depreciating currency.

\subsubsection{Quality of Institutions}

The quality of a country's institutions is an essential factor in attracting FDI for various reasons. Measuring institutional factors, however, is not an easy task. Poor institutions are known to increase investment costs and reduce profits. They also allow for corruptions which might scare off some investors. Good governance, on the other hand, is linked with higher economic growth and also attracts more FDI (Yu \& Walsh 2010). Dutta, Kar \& Saha (2017) did research on the topic of whether corruption can affect the relationship between FDI and human capital. They highlight that corruption not only increases bribery, but also decreases the inflow of FDI because of the risk of firms having to deal with breached contracts. The quality of government services and infrastructure is reduced significantly, favoring local firms a lot more than foreign forms. The same opinion is shared by Demir (2016) as he indicates that an increase in FDI can result in higher chances for bribery and also increase the competition between countries to attract the most business for local markets. This can lead to bypassing local laws and regulations or other corrupt practices just to secure the most investments for their own market. Das (2013) points out that poor institutional factors in a country such as high tax rates, corruption, regulatory uncertainty, government interference and insufficient protection of property rights can lead investors to look for other countries to invest in with better institutions.

\subsection{Market, Resource and Efficiency Seeking FDI}

Kucharčíková (2013) states that in 2011 the inflow of foreign direct investment increased to 16 percent. It was the first time this happened since the pre-crisis of 2005-2007 and the global economic crisis of 2008-2009. Despite the world crisis, global foreign direct investment flows reached at least USD 1.5 trillion. This is however, still 23 percent below the peak of 2007. Developed countries had an increase of 21 percent, USD 748 billion, and developing countries accounted for almost half of the global FDI which was a new record of USD 684 billion.

The first type of FDI is called, market-seeking FDI and is also known as horizontal FDI. It involves replicas of production facilities in host countries and the aim is to serve the local market as other regional markets. Besides serving local markets, market size, market growth and obstacles to access local markets like tariffs and transport costs favor this kind of FDI. Elia et al. (2009) note that market-seeking FDI, because of the externalities created by the demand for specialized inputs and high skilled labor, can expand to the whole economic area the parent company operates in. Garretsen \& Peeters (2009) point out that the possibility to escape trade costs gives firms the change to use horizontal or market-seeking FDI, but the cost that comes with the whole process of setting up a production company abroad in another country discourages FDI.

The second type is efficiency-seeking FDI. It takes place when firms can still profit from activities that are 
geographically dispersed in the case of economies of scale. Noorbakhsh et al. (2001) state that in the case of efficiency-seeking FDI, the cost of labor plays an important role for foreign investors in their locational decisions. Efficiency-seeking FDI happens more in developing countries where the cost of labor is cheaper compared to developed countries. The third type is resource-seeking FDI. This is when firms decide to invest abroad with the hope of obtaining resources that are not available in the home country, such as natural resources, raw materials, or low-cost labor. In contrast to horizontal FDI, vertical or export oriented FDI involves the relocation of parts of the production chain to the host country. However, this type of FDI does not apply to developed countries.

\subsection{FDI and Human Capital in the Netherlands}

Foreign-owned firms in the Netherlands export almost twice more than domestically owned firms. The export intensity of these foreign-owned firms is also above the OECD average (OECD. 2017). This is due to the reform plans of avoiding double taxation of corporate profits and by making sure that Dutch businesses can compete on an equal footing abroad. Also important is the ease of doing business in the Netherlands. MNE's don't have to wait too long to start their business. Being an attractive location for MNEs attracts a high number of FDI. With a high inflow of FDI and a very skilled population, the country gets to benefit by placing its labor force in these MNEs and getting the chance to acquire important skills, know-how, and the newest technology. The spillovers from these MNE's to the domestic companies can also be of great benefit to the country. All of this causes the Netherlands to be a country with key specific factors such as high savings rates with an increasing share of foreign investment and the presence of large multinationals with both positive net exports and outgoing FDI.

According to the Lisbon Counsel Policy brief by Ederer (2006), human capital utilization has been increasing for the past two decades in the EU. Three countries have performed greatly by rising from the bottom all the way to the top. One of these countries is the Netherlands. Compared to other European countries it is very clear to see that the Netherlands has a very active workforce. It is way higher than in other big countries like Germany and Spain.

In terms of employment, as of 2016, at least $75 \%$ of people aged 15 to 64 in the Netherlands have a paid job. This is above the OECD employment average of $67 \%$. In the case of men and women, at least $80 \%$ of Dutch men are in paid work, compared with $70 \%$ of women. The most important requirements for finding a job in the Netherlands, are good education and skills. At least 77\% of all Dutch adults aged 25-64 have completed upper secondary education, this is also higher than the OECD average of $74 \%$. Comparing men and women, the number of men that have successfully completed high school is $78 \%$ and for women that number is $76 \%$. Looking at the quality of the Dutch education system, it is also clear that compared to other OECD countries, the Dutch score very high on the OECD Programme for International Student Assessment (PISA). In terms of the quality of the education system, the average student scored 508 in reading literacy, maths, and science. This score is also higher than the OECD average of 486. With scores higher than all the OECD averages Netherlands can be seen as one of the strongest OECD countries in students' skills (OECD Economic Surveys: Netherlands 2018).

\section{Data and Methods}

\subsection{Data Sources and Types}

This study made use of data obtained from the World Bank, the World Development Indicators. The WDI provides a wide coverage of data flows from all sources and for a long period of time (1970-2018). The relevant data has been collected from 1971-2016. The variables used are foreign direct investment and secondary school enrollment as a proxy for human capital.

The study starts by presenting the descriptive statistics (i.e. means, standard deviations, minimum and maximum values of variables) and continues with the tools used for analysis. Afterward, the study carried out unit tests using the Augmented Dickey-Fuller (DF) unit root test to ensure that the time series are integrated of order 1.

This was done to test whether the data series variables are stationary or non-stationary. The unit root test is considered as the null hypothesis if it exists in the data series, while the non-existence of it in the data series is considered as the alternative hypothesis. The Augmented Dickey-Fuller test is specified as follows:

The general hypothesis:

$H_{0}$ : There is Non-stationary (there is unit root)

$H_{a}$ : Stationary (no unit root)

In order to test the null hypothesis, the $\mathrm{t}$ statistic has to be calculated and then compared to the critical values to make a decision. The null hypothesis of an implied non-stationary data series is rejected, if the test statistic is greater than the critical values (test statistic > critical values). When the null hypothesis is rejected, the time 
series data becomes stationary, meaning no unit root.

In order to remove outliers or any data contamination the robust regression test has been performed. Based on the weighted values we can decide whether the results are robust or not. If the weighted values are less than 1 , then we can assume that the results are not contaminated, but if the values are higher than 1, then the data is not robust and consists of outliers. The study undertook the Johanson Cointegration test which is used to evaluate the long-term co-movement of variables used during the research. If the test indicates that there is a cointegrating vector, it is assumed that the tested series in the long-run will not drift apart (Maggiora and Skerman, 2009). The software used to analyze the data was Stata MP 14.

\subsubsection{Model Specification}

The Johansen Cointegration is a modeling process incorporating non-stationary with both long-term relationships and short-term dynamics. After calculating the unit test, if the study observes that the time series data is non-stationary and integrated of order 1, then the Johansen Cointegration test is used to establish the existence of a long-run relationship between the variables. Integrated of order 1 means the series becomes stationary after differentiating it once. The equation for the Johansen Cointegration test is specified as:

$$
\begin{aligned}
& n \log F D I=C_{1} * n \log F D I_{t-i}+C_{2} * n \log S E C_{t-j}+\varepsilon_{i j} \\
& n \log S E C=C_{3} * \log S E C_{t-j}+C_{4} * n \log F D I_{t-i}+\varepsilon_{i j}
\end{aligned}
$$

Equation 1

Equation 2

Where $n \log$ denotes natural logarithm of FDI (Foreign Direct Investment), Human capital (SEC), $\varepsilon$ is the error term.

According to Maggiora \& Skerman (2009), there are two test statistics for the Johansen Cointegration method: the Trace Test and the Maximum Eigenvalue Test. The Trace test is a joint test and tests the null hypothesis of no cointegration $\left(\mathrm{H}_{0}\right)$ against the alternative hypothesis of cointegration $\left(\mathrm{H}_{1}\right)$. The Maximum Eigenvalue test on the other hand, conducts tests on each eigenvalue separately.

\section{Results and Discussion}

\subsection{Descriptive and Diagnostic Statistics}

The mean, standard deviation, minimum and maximum of the variables are presented in Table 1 . The study analysis is restricted to only data from 1971-2016 (i.e. 46 years), obtained from the World Bank. Because the original values of the variables are too big, they were converted to their log form and also differentiated. These changes, however, do not affect their natural characteristics. The results show that FDI has an average value of 10.82208 , a minimum value of .4827092 and a maximum value of 87.44259 . The average score for SEC is 113.0983 , the minimum score is 75.38679 and the maximum score 140.6905 .

Table 1. Descriptive statistics

\begin{tabular}{llllll}
\hline VARIABLE & OBS. & MEAN & STD. DEV. & MIN & MAX \\
\hline FDI & 46 & 10.82208 & 16.73765 & .4827092 & 87.44259 \\
SEC 1 & 46 & 113.0983 & 18.05329 & 75.38679 & 140.6905 \\
\hline
\end{tabular}

Notes. SEC=secondary school enrolment; FDI=foreign direct investment.

The Augmented Dickey-Fuller unit root test is used to perform stationary tests. The null hypothesis should be rejected when the test statistic is greater than the critical value of 5\% and the alternative hypothesis accepted. The results in Table 2 show that at drift lag 1, the test statistic of LNFDI has a value of -1.153 , at $1 \%$ a critical value of -2.421 , at $5 \%$ a critical value of -1.683 and at $10 \%$ a value of -1.303 . The number of observations is 44 . At lag 1 , the test statistic is smaller than the critical value of $5 \%$. In this case, the null hypothesis cannot be rejected.

Table 2. Augmented Dickey-Fuller Test for Unit Root

\begin{tabular}{|l|l|l|l|l|}
\hline & TEST STATISTIC & 1\% CRITICAL VALUE & 5\% CRITICAL VALUE & 10\% CRITICAL VALUE \\
\hline $\mathrm{Z}(\mathrm{T})$ & -1.153 & -2.421 & -1.683 & -1.303 \\
\hline DFULLER LNFDI, DRIFT LAGS (1) \\
NUMBER OF OBS. $=$ 44 \\
$\mathrm{Z}(\mathrm{T})$ HAS T-DISTRIBUTIONS
\end{tabular}

$\mathrm{P}$-value for $\mathrm{Z}(\mathrm{t})=0.1277$ 
Table 3 presents the results of the augmented DF test for LNFDI at no constant lags 1 . The value of the test statistic is -0.306 . The critical value at $1 \%$ has a score of -2.630 , at $5 \%$ a score of -1.950 and at $10 \%$ the score is -1.608 . The test statistic at no constant lags 1 is also smaller than the critical value of $5 \%$. The null hypothesis cannot be rejected.

Table 3. Augmented Dickey-Fuller Test for Unit Root: LNFDI No constant Lags 1

\begin{tabular}{|l|l|l|l|l|}
\hline & TEST STATISTIC & $1 \%$ CRITICAL VALUE & $5 \%$ CRITICAL VALUE & $10 \%$ CRITICAL VALUE \\
\hline $\mathrm{Z}(\mathrm{T})$ & -0.306 & -2.630 & -1.950 & -1.608 \\
\hline DFULLER LNFDI, NOCONSTANT LAGS (1) & \\
NUMBER OF OBS. = 44 \\
INTERPOLATED DICKEY-FULLER
\end{tabular}

Table 4 presents the results for LNSEC1 at drift lags 1 . The number of observations is 44 and the test statistic score is -2.112 . The score of -2.421 is at a critical value of $1 \%$ and at $5 \%$ the critical value is -1.683 . At a critical value of $10 \%$, the score is -1.303 . The p-value is 0.0204 . For LNSEC1 at lag 1 , the test statistic is greater than the critical value of $5 \%$. The null hypothesis can be rejected.

Table 4. Augmented Dickey-Fuller Test for Unit Root: LNSEC1 drift Lags 1

\begin{tabular}{|l|l|l|l|l|}
\hline & TEST STATISTIC & $1 \%$ CRITICAL VALUE & $5 \%$ CRITICAL VALUE & $10 \%$ CRITICAL VALUE \\
\hline $\mathrm{Z}(\mathrm{T})$ & -2.112 & -2.421 & -1.683 & -1.303 \\
\hline DFULLER LNFDI, DRIFT LAGS (1) \\
NUMBER OF OBS. = 44 \\
Z(T) HAS T-DISTRIBUTIONS
\end{tabular}

$P$-value for $Z(t)=0.0204$

Table 5 presents the results for LNSEC1 at no constant lag 1. The test statistic has a value of 1.728 and the critical value at $1 \%$ is -2.630 . At $5 \%$ the critical value is -1.950 and -1.608 at $10 \%$. The test statistic is greater than the critical value of $5 \%$. The null hypothesis can be rejected.

Table 5. Augmented Dickey-Fuller test for Unit Root: LNSEC1 No constant Lags 1

\begin{tabular}{|l|l|l|l|l|}
\hline & TEST STATISTIC & $1 \%$ CRITICAL VALUE & $5 \%$ CRITICAL VALUE & $10 \%$ CRITICAL VALUE \\
\hline $\mathrm{Z}(\mathrm{T})$ & 1.728 & -2.630 & -1.950 & -1.608 \\
\hline DFULLER LNFDI, NOCONSTANT $(1)$ & \\
NUMBER OF OBS. = 44 \\
INTERPOLATED DICKEY-FULLER
\end{tabular}

The study uses the Robust Regression test to find out whether the results are robust or not. Table 6 presents the results of the robustness check of this research. In order for the results to be robust, the weighted values should be less than 1 . It is very clear in the above table that all the weighted values are less than 1 and the $P$ value is significant at 0.000 . This means that the results of this study are robust, and the data does not consist of any outliers or contamination.

Table 6. Robust Regression Test

\begin{tabular}{|c|c|c|c|c|c|c|}
\hline LNFDI & COEF. & STD. ERR & $\mathrm{T}$ & $\mathrm{P}>\mathrm{T}$ & $95 \% \mathrm{CON}$ & INTERVAL \\
\hline LNSEC & 16.37788 & 1.473121 & 11.12 & 0.000 & 13.409 & 19.34676 \\
\hline CONS & -264.8802 & 23.94648 & -11.06 & 0.000 & -313.1412 & -216.6192 \\
\hline \multicolumn{3}{|c|}{$\begin{array}{l}\text { NUMBER OF OBS. }=46 \\
F(1,44)=123,61 \\
\text { PROD }>F=0.0000\end{array}$} & \multicolumn{4}{|c|}{$\begin{array}{l}\text { Huber iteration 1: maximum difference in weights }=0.5196 \\
\text { Huber iteration 2: maximum difference in weights }=0.6029 \\
\text { Huber iteration 3: maximum difference in weights }=0.1367 \\
\text { Biweight iteration 4: maximum difference in weights }=0.1580 \\
\text { Biweight iteration 5: maximum difference in weights }=0.0047\end{array}$} \\
\hline
\end{tabular}




\subsection{Causal Relationship (Based on Johansen Cointegration Test)}

The Johansen Cointegration test is performed when the time series are non-stationary at levels. From the results shown above in table 2 till 5, the study observed that the series are non-stationary. Performing a cointegration test is necessary and based on the results it is clear that there exists a long-run relationship between the variables, despite the fact that the series are drifting apart or either trending upwards or downwards. The criteria for the Johansen Cointegration test is that the trace statistic should be smaller than the critical value to be considered significant. If the trace statistics is bigger than the critical value, the null hypothesis should be rejected. This means there is no cointegration between the variables.

Table 7 presents the results for LNFDI LNSEC at a maximum trend value. In the first part at rank zero, the trace statistic is 20.2092 and the critical value 18.17. The eigenvalue at rank 1 is 0.31497 , the trace statistic 3.5641 and the critical value 3.74. The number of observations is 44 and the lags 2 . At rank zero, the trace statistic is bigger than the critical value and at rank 1 the trace statistics is smaller than the critical value. This means that only at rank one is there cointegration between the variables. The null hypothesis should be rejected at rank zero.

The second part of the table shows that at rank zero the value for the trace statistic is 16.6451 and the critical value is 16.87 . The eigenvalue at rank 1 is 0.31497 , the trace statistic is 3.5641 and the critical value is 3.74 . The trace statistic is smaller than the critical value at both ranks. This means that there is cointegration between the variables on both ranks.

Table 7. Johansen test for cointegration: LNFDI LNSEC1, trend max

\begin{tabular}{|l|l|l|l|l|}
\hline RANK & LL & EIGENVALUE & TRACE STATISTIC & 5\% CRITICAL VALUE \\
\hline 0 & 52.68518 &. & 20.2092 & 18.17 \\
\hline 1 & 61.007745 & 0.31497 & 3.5641 & 3.74 \\
\hline 2 & 62.789786 & 0.07781 & & \\
\hline $\begin{array}{l}\text { TREND: TREND } \\
\text { SAMPLE: } 3-46, \text { NUMBER OF OBS. }=44 \\
\text { MAXIMUM, LAGS }=2\end{array}$ \\
\hline RANK & LL & EIGENVALUE & TRACE STATISTIC & 5\% CRITICAL VALUE \\
\hline 0 & 52.68518 &. & 16.6451 & 16.87 \\
\hline 1 & 61.007745 & 0.31497 & 3.5641 & 3.74 \\
\hline 2 & 62.789786 & 0.07781 & & \\
\hline
\end{tabular}

Table 8 presents the results for LNFDI LNSEC1 at a maximum constant value. In the first part at rank zero, the trace statistic is 10.1721 and the critical value 15.41 . The eigenvalue at rank 1 is 0.13741 , the trace statistic 3.6684 and the critical value 3.76. The number of observations is 44 and the lags 2 . At rank zero, the trace statistic is smaller than the critical value and at rank 1 the trace statistics is also smaller than the critical value. This means that in both cases there exist cointegration between the variables.

The second part of the table shows that at rank zero the value for the trace statistic is 6.5038 and the critical value is 14.07 . The eigenvalue at rank 1 is 0.13741 , the trace statistic is 3.6684 and the critical value 3.74 . The trace statistic is smaller than the critical value at both ranks. This means that there is cointegration between the variables on both ranks.

Table 8. Johansen Test for Cointegration: LNFDI LNSEC1, TREND CONSTANT MAX

\begin{tabular}{|l|l|l|l|l|}
\hline RANK & LL & EIGENVALUE & TRACE STATISTIC & $5 \%$ CRITICAL VALUE \\
\hline 0 & 51.787201 &. & 10.1721 & 15.41 \\
\hline 1 & 55.039078 & 0.13741 & 3.6684 & 3.76 \\
\hline 2 & 56.873263 & 0.07999 & & \\
\hline $\begin{array}{l}\text { TREND: TREND } \\
\text { SAMPLE: 3-46, NUMBER OF OBS. }=44 \\
\text { MAXIMUM, LAGS }=2\end{array}$ \\
\hline RANK & LL & EIGENVALUE & TRACE STATISTIC & $5 \%$ CRITICAL VALUE \\
\hline 0 & 51.787201 &. & 6.5038 & 14.07 \\
\hline 1 & 55.039078 & 0.13741 & 3.6684 & 3.76 \\
\hline 2 & 56.873263 & 0.07999 & & \\
\hline
\end{tabular}




\section{Conclusion \& Recommendations}

The climate investment of a country is dependent on many things. According to the literature, some of the most important factors are the geographical situation (availability of natural resources, size of the domestic market, and the distance to other markets), infrastructure, socioeconomic policy, and the quality of the institutions (especially in the areas of labor and finance).

The study used the Johansen cointegration test to determine whether there is a causal relationship between the inflow of foreign direct investment and human capital in the Netherlands. The study fills in a literature gap within the Dutch context of what the impact might be of foreign direct investment on the country's human capital. Located at the center of Europe the Netherlands is a global leader of FDI in- and outflows. They also have a very skilled labor force with an employment rate of at least $80 \%$. The study used secondary data obtained from the World Bank, the World Development Indicators. The WDI provides wide coverage of data flows from all sources and for a long period of time and the relevant data used is collected from 1971-2016. To avoid any spurious regression the study carried out the Augmented Dickey-Fuller test to determine if the data is stationary or non-stationary. The results show that the data used for this research is non-stationary, because it does not evolve around zero. Table 2 at drift lags 1 shows that for LNFDI, the test statistic -1.153 smaller is than -1.303 , the critical value of 5\%. The null hypothesis cannot be rejected in this case. Table 3 shows that at noconstant lags 1 for LNFDI the test statistic of negative 0.306 also smaller is than negative 1.950 , the critical value of $5 \%$. The null hypothesis can therefore not be rejected. Table 4 at drift lags 1 for LNSEC1 shows that the test statistic of -2.112 greater is than -1.683 , the critical value of $5 \%$. The null hypothesis can be rejected in this case. Table 5 at noconstant lags 1 for LNSEC1 has a test statistic of 1.728 which is greater than the 5\% critical value of -1.950 . The null hypothesis can also be rejected in this case. After the Augmented Dickey-Fuller test the study employed the Johansen cointegration test and based on the results of the trace test, this study reports that there exists one cointegrating vector. In other words, there is evidence of a long-run linear relationship among the variables. Afterwards, each variable was tested for causality to determine whether there exists a bidirectional or unidirectional causality among the two variables. There are other factors determining the inflow of foreign direct investment into the Netherlands. Since the Netherlands already has a very skilled labor force, the cost of labor can be higher than other European countries which in turn can explain why the country's human capital is not the most important determinant of their FDI inflows. There can also be other factors such as trade openness, domestic investment or the quality of institutions which are attractive to foreign investors and causes the increase of the inflow of FDI into the Netherlands. All of the above points can be used for further research.

Based on the results the study observed that there is no relationship between the inflow of foreign direct investment and human capital in the Netherlands. Having a very skilled labor force is not the reason why investors decide to invest in the Netherlands. The inflow of foreign direct investment into the country is determined by other factors. For further studies, it is recommended for others to continue with the study and increase the number of variables.

\section{References}

Adefabi, R. A. (2011). Effects of FDI and Human capital on Economic Growth in Sub-Saharan Africa. https://doi.org/10.3923/pjssci.2011.32.38

Al-sadiq, A. J. (2013). Outward Foreign Direct Investment and Domestic Investment: The Case of Developing Countries. IMF Working Papers, 13(52), 1. https://doi.org/10.5089/9781475517934.001

Boarini, R., \& Liu, G. (2012). Approaches to Measuring the Stock of Human Capital.

Borenszstein, E., De Gregorio, J., \& Lee, J. W. (1995). How Does Foreign Direct Investment Affect Economic Growth. https://doi.org/10.3386/w5057

Chakrabarti, A. (2001). The determinants of foreign direct investment: Sensitivity analyses of cross-country regressions. Kyklos, 54(1), 89-114. https://doi.org/10.1111/1467-6435.00142

Das, K. C. (2013). Home Country Determinants of Outward FDI from Developing Countries. Margin, 7(1), 93-116. https://doi.org/10.1177/0973801012466104

Demir, F. (2016). Effects of FDI Flows on Institutional Development: Does It Matter Where the Investors are from? World Development, 78, 341-359. https://doi.org/10.1016/j.worlddev.2015.10.001

Demirhan, E., \& Masca, M. (2008). Determinants of foreign direct investment flows to developing countries: a cross-sectional analysis. Prague Economic Papers, 17(4), 356-369. https://doi.org/10.18267/j.pep.337

DOROŻYŃSKA, A., \& DOROŻYŃSKI, T. (2014). The Role of Human Capital in Attracting FDI: The Case of the Lodz Region. Ssrn, 221-241. https://doi.org/10.2139/ssrn.1726038 
Dulam, T. (2015). Brain Drain or Brain Gain: The case of Suriname, 1-156. Retrieved from file:///G:/EDrive/Mobility Study/Brain Drain or Brain Gain.pdf

Dutta, N., Kar, S., \& Saha, S. (2017). Human capital and FDI: How does corruption affect the relationship? Economic Analysis and Policy, 56, 126-134. https://doi.org/10.1016/j.eap.2017.08.007

Ederer, P. (2006). Innovation at Work: The European Human Capital Index, 1-24. Retrieved from http://scholar.google.com/scholar?hl=en\&btnG=Search\&q=intitle:Innovation+at+Work:+The+European+H uman+Capital+Index\#0

Elia, S., Mariotti, I., \& Piscitello, L. (2009). The impact of outward FDI on the home country's labour demand and skill composition. International Business Review, 18(4), 357-372. https://doi.org/10.1016/j.ibusrev.2009.04.001

Fazekas, K. (2000). The impact of foreign direct investment inflows on regional labour markets in Hungary. Budapest Working Papers on the Labour Market.

Garretsen, H., \& Peeters, J. (2009). FDI and the relevance of spatial linkages: do third-country effects matter for Dutch FDI? Review of World Economics, 145(2), 319-338. https://doi.org/10.1007/s10290-009-0018-1

Jansen, W., \& Stokman, C. (2004). Foreign Direct Investment and International Business Cycle Comovement. ECB Working Paper Series, 401, 0-25. Retrieved from http://localhost/ alexispe/Resumes/jansenstokman2004.pdf

Jude, C., \& Silaghi, M. I. P. (2015). Employment effects of foreign direct investment: New evidence from Central and Eastern European countries. International Economics, 145, 32-49. https://doi.org/10.1016/j.inteco.2015.02.003

Kucharčíková, A. (2013). Foreign Direct Investment in the Context of the Economic Recession in Slovakia. Journal of Finance and Economics, 1(1), 1-7. https://doi.org/10.12691/jfe-1-1-1

Liu, G., \& Fraumeni, B. M. (2014). Human capital measurement: country experiences and international initiatives. The 3rd OECD World Forum, 1-36. https://doi.org/10.1007/s10887-007-9011-5

Maggiora, D. D., \& Skerman, R. (2009). Johansen Cointegration Analysis Of American And European Stock Market Indices: An Empirical Study. Master Thesis in Finance. May 2009.

Mihaela, S. (2016). The relation between economic growth and foreign direct investment during the economic crisis in the European Union. Zb. rad. Ekon. fak. Rij., 34(1),187-213. https://doi.org/10.18045/zbefri.2016.1.187

Moran, T. (2006). Harnessing Foreign Direct Investment for Development.

Noorbakhsh, F., Paloni, A., \& Youssef, A. L. I. (2001). Human Capital and FDI In - ows to Developing Countries: New Empirical Evidence. World Development, 29(9). https://doi.org/10.1016/S0305-750X(01)00054-7

OECD. (2017). International trade, foreign direct investment and global value chains 2017, 1-9.

Statistics Netherlands. (2008). Figures on the investment climate in the Netherlands 2008.U.S. Department of State. (2015). THE NETHERLANDS.

UNCTAD. (2018). World Investment Report, 2018. Challenge, 43(3), 107-114. https://doi.org/10.1080/05775132.2000.11472157

UNECE. (2016). Guide on Measuring Human Capital Guide on Measuring Human Capital.

World Economic Forum. (2017). The Global Human Capital Report.

Xu, X., \& Sylwester, K. (2016). The effects of foreign direct investment on emigration: The roles of FDI source country, education, and gender. Economic Modelling, 55, 401-409. https://doi.org/10.1016/j.econmod.2016.03.001

Yu, J., \& Walsh, J. P. (2010). Determinants of Foreign Direct Investment: A Sectoral and Institutional Approach. IMF Working Papers, 10(187), 1. https://doi.org/10.5089/9781455202218.001

Zhang, X., \& Daly, K. (2011). Location Determinants of China's Outward Foreign Direct Investment. Emerging Markets Review, 25(6), 1-27. https://doi.org/10.1111/cwe.12218

\section{Copyrights}

Copyright for this article is retained by the author(s), with first publication rights granted to the journal.

This is an open-access article distributed under the terms and conditions of the Creative Commons Attribution license (http://creativecommons.org/licenses/by/4.0/). 